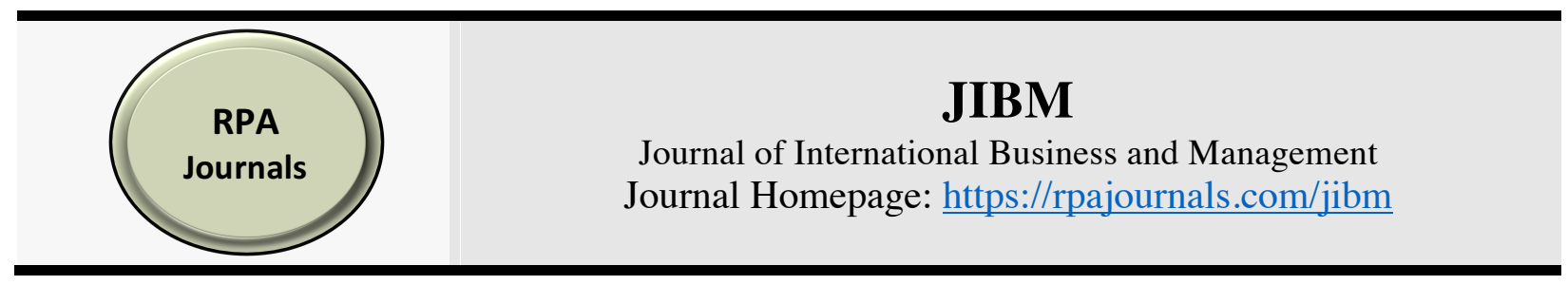

\title{
Conflict Management and Job Satisfaction in Indonesia's Public Organization
}

\author{
Saka Aditya ${ }^{1}$ \\ Anton A Setyawan ${ }^{2 *}$ \\ Muhammadiyah University of Surakarta, Indonesia
}

\begin{abstract}
This research aims to determine which styles are applied to manage and handle conflict and whether conflict management has an effect on job satisfaction and in public sector. The research was conducted in December 2017 in the government public sector of Indonesia. The data in this research was collected by using questionnaire. The questionnaire used ROCI-II (integrating, avoiding, obliging, dominating, compromising style) instruments for conflict management and JSS Paul Spector on job satisfaction. The results of this study showed that government public sector workers used collaborative conflict management style (integrating style) in conflict management and handling. Conflict management has 5 conflict management styles, from the 5 factors, only 2 factors are formed, namely factor 1 and 2 . Factor 1 includes the style of collaboration (integrating style), accommodation (obliging style), and compromise (compromising style). Factor 2 includes dominating style and avoidance (avoiding style).
\end{abstract}

Keywords: Conflict Management, Conflict Management style, Job Satisfaction, Public Sector, Indonesia

*Corresponding author: Anton A Setyawan; Email: anton.setyawan@ums.ac.id DOI: https://doi.org/10.37227/JIBM-2021-01-134

\section{Introduction}

People have their own different characters, as well as the resources they need to navigate their life. This difference leads to competition among individuals and also can lead to a conflict. The conflict itself rises and presents in every life and also appears in the nature of organization. Organization has a structure and is filled with various individuals with their various characters. In the process of achieving the goal, conflict is often created. If the conflict is well treated within the organization, the conflict has a good role. However, there is still a chance that the opposite effect will rise. Therefore, management conflict is needed to transform the conflict into something that will give good influence on the organization. Kurt Lewin (1948) argues that conflict arises when many people have power and influence, yet have different interests within one organization.

Conflicts that arise in the organization have an interpersonal team conflict context. In the other words, it depends on the management. The success or failure of the management of conflict relies heavily on group members. According to Somech et al (2009) on the implications of conflict management, members of the organization should be more sensitive and able to face the conflict so 
that they can distribute their work effectively and equitably to achieve their goals. The ability of conflict management is a very important key for every manager (Quijada, 2016). A manager must be able to manage, lead and pursue members to provide optimal results of work and achieve organizational goals.

Staff is a part of the organization and is a very important source to realize organizational goals. Meanwhile, conflict is part of organizational life, and the output of individual teamwork within the organization (Ahmed, 2015). Conflict affects performance and productivity. Moreover, it will also affect health and prosperity of an individual when it is not properly managed. Since the employee is a very important human resource, manager should give more attention on them.

Those are some definitions of conflict management from some literatures. There are also several studies that have been conducted on conflict management and its relation to job satisfaction. These earlier studies become the basis to conduct this research. The first research is from Ahmed (2015) from El-Minia University Egypt, entitled the relationship between conflict management styles, job satisfaction, and organizational commitment between public and private sector workers. This research was conducted by using 320 sample consist of public sector and private sector. The results of this study conclude that there is a significant relationship between conflict management on job satisfaction and organizational commitment.

One thing that must be considered and supported by the manager is the employees' job satisfaction (Mehrad, 2015). According to Maharjan (2012) job satisfaction is defined as organizational sentiments that must be considered and should be facilitated by managers in accordance with individual needs of the organization. Therefore, if the conflict is handled appropriately, it can increase job satisfaction, however, it can decrease job satisfaction if it is handled inappropriately which impact on decreasing work performance (Williams, 2011).

Public service sector can be defined as any service activities undertaken by public service providers as an effort to fulfill public needs and the implementation of the provisions of legislation (Mahmudi, 2007). In this case, according to Mahmudi (2007), public service providers are government agencies that include:

a. The ministry's work unit

b. Department

c. Non Departmental Government Institution.

d. Secretariat of the State Institutions

e. State Owned Enterprises (BUMN)

f. Regional Owned Enterprises (BUMD)

g. Other Government Agencies like government offices and agencies.

Christensen, et al (2007) states that the public sector has three characters, namely: all public sectors have leaders elected based on the largest number of votes, public sector is very different from private sector since the public sector is multifunctional and the whole part of public sector is different from the private sector viewed from what is done. These public sector services of the government have basic needs to be provided include:

a. Health

b. Basic education

c. Basic needs of society

In the implementation of public services, the government has a responsibility to provide social services in order to create community welfare. In addition, the government as the implementer of public service providers has an obligation to provide public services to the community (Mahmudi, 2007). Mahmudi (2007) explained that this public service consists of three things, namely to perform administrative services, goods, and services.

Administrative services are services in the form of providing various forms of documents required by the public, for example the making of identity cards (KTP), land certificates, birth certificates, deeds of death, book of Owners of Motor Vehicles (BPKB), Building Permit (IMB), and passport. On goods service, it is done by providing services in the form of products that become public needs, for example telephone network, electricity supply, and water supply. Service is a form of service that produces various forms of services needed by the public, for example, high and middle 
education, health care, transportation organizers, postal services, environmental sanitation, waste cleanliness, drainage, roads and sidewalks, disaster management and social services (social insurance). The resolution of the conflict requires an effective and efficient management in order to minimize the negative impact on the organization. Conflict management is a strategic step to manage conflict to its completion and is expected to have a positive impact on both parties. This study was conducted with the aim to determine whether the style of conflict management has an effect on job satisfaction. This research is also intended to identify and identify the conflict management style that is implemented by public sector workers in handling and resolving conflicts within their organization.

\section{Literature Review}

\section{Relation between conflict management and job satisfaction}

High job satisfaction will encourage workers to work better, have an effective conflict management style, and be loyal to the organization and become a distinct advantage for the organization (Raditya, 2012). Personal dispositions, job responsibilities, supervision, co-workers, and salary are the factors that establish job satisfaction (Miller, 2007). Workers having a team with the ability to manage conflict effectively can produce high performance productivity and job satisfaction (Raditya, 2012).

\section{Conflict Management}

Conflict is a theme that has been studied by many researchers. Conflict can be interpreted as a distinct interest among people (Thompson, 1998). Rahim (2001) argues that conflict is something that arises naturally among humans when two or more social entities; such as individuals, groups, or organizations interacting with each other in achieving their goals.

Kurt lewinlewin (1948) argues that conflict will arise when those who have power and influence but have different interests are in one organization. Putnam and Wilson (1982) also argue that this conflict may arise in interpersonal relationships between subordinates, superiors, and partners and in an intragroup and intergroup relationship in a workplace and the whole organization. In mitigating the negative effects caused by the conflict, conflict management will take place to prevent the organization from moving misdirected from its objectives.

Conflict management according to Wirawan (2009) is a strategy whereby organizations and individuals work to recognize and manage differences, by the efficiency of the financial and human costs of conflict management difficulties, while conflict alignment serves as a source of innovation and development. Prasad and Junni (2017) argue that conflict management can be interpreted as an implementation of the top management team's innovation by formulating strategies directly and in the process of compilation must be adaptive, sensitive and understand the dynamics that occur, such as communication flow, social integration, and environment. In managing a conflict according to Rahim (1983), there are five styles that can be applied for managing conflicts, such as collaborative style, accommodation, dominating style, avoiding style and compromising style.

Wahyudi (2015) revealed that conflicts arising within the organization can arise due to the influence of several trigger factors such as individual factors and organizations. Style and way of leadership gives influence and can cause a conflict. Organization always has its own culture in carrying out its activities. Each leader has its own characteristics in the style of leadership, so it becomes important to socialize, approach and explain to subordinates to avoid miscommunication. Individual factors affect the emergence of a conflict. Internal factors are the presence of resistant individuals and maintain a culture or rules rigidly and less flexible in accepting new things, then the emergence of a conflict within the organization will arise, which begins on the characteristics or individual characters within the organization.

Organizational factors can also influence the emergence of a conflict, competition on the use of resources that can be in the form of money, materials or other means. Although the amount is limited, it can be the cause of the conflict. Each department within an organization has its specialization of functions, duties and fields. If the differences are not directed or driven appropriately, it will provided conflict of interest between departments. 
Conflict is caused by dependence between one group and another. Interdependence of tasks is crucial in the organization. If one department is obstructed,so do the other departmental jobs. There will be conflict within the organization. The organization will run well if all individuals, departments synergize in the same perception in this regard to achieve organizational goals. There will always be a certain group that has a negative or different perception within an organization. This occurs when one group is treated differently from the other. This thing will be a trigger to create conflict within an organization. The jurisdictional uncertainty will result a conflict, the boundaries of unclear or colliding rules. This thing will create overlapping responsibilities within an organization and guiding the organization into conflict.

Organizational conflict has several forms: intrapersonal, interpersonal, intragroup, and intergroup conflicts (Rahim, 2001). Intrapersonal conflicts, according to Rahim (2001), is a conflict that occurs when an organization member is required to perform a job that is inconsistent with the person's roles, skills, values and goals. Intrapersonal conflicts such as the definition of Rahim (2001), will occur when the person finds himself on his site that what he does and decisions do not match the value or thing that the person really wants. According to Nastase (2007), this conflict can arise due to externalenvironment or the person himself. An example of this conflict can be taken from a group but there is a family of group leaders in it. This forces leaders to manage group responsibilities with family members and with non-family groups. It contains great responsibility, and allows other resources to be less interested in value or there are objective differences in individuals engaged in certain activities (Nastase, 2007).

Interpersonal conflict is a conflict between two or more individuals working together in groups. These conflicts are triggered by differences among individuals, including personality, culture, attitudes, values, perceptions, and so on (Beheshtifar\&Zare, 2013). Interpersonal conflict is a process whereby an individual or a department making othersfrustrated to get the desired results (Beheshtifar\&Zare, 2013).

Intragroup conflicts are conflicts between group members in the organization, two or more sub-groups within a group related to the outcomes of work, tasks, procedures, and so on (Rahim, 2001). Intergroup conflicts can be defined as conflicts that occur between two or more units or groups within an organization. For example,there are conflicts between management and workers, or the finance and operations department (Rahim, 2001).

There are five styles to deal with a conflict in conducting conflict management. These five styles are integrating, obliging, dominating, avoiding, and compromising style (Rahim, 2001). Integrating style has a high attention to self and others by individuals who use it. This style becomes problem solvers and the character always involves all members of the group in the distribution of information. According to Rahim (2001), integrating style can also be used as a way to check the differences in order to achieve the required solutions. Obliging style is different from integrating style where caring and attention to self is low but high in others, the obliging style can also be called the style of accommodation (Rahim, 2001).

Style of accommodation (obliging style) is different from the style of collaboration where caring and attention to self is low but high in others, the bonding style can also be called the style of accommodation (Rahim, 2001). Compromising style based on WIlliam (2011) can be defined as a situation in which each of the groups involved in the conflict make a deal on several points based on the results of a joint compromise. Kreitner and kinicki (2010) argue that the dominating style is a style of conflict management that forces other parties involved in the conflict to have the party obey. When described in accordance with its definition, the style of domination has a very low character toward others in the sense of attention, and is very high on its own concern. For avoiding style, Williams (2011) defines the style of conflict management by ignoring the conflict as its action even though the individual is well aware of the surrounding conflicts. Avoiding style tends to be less concerned about both yourself and others.

\section{Job Satisfaction}

Staff is a very important asset in human resources, as well as job satisfaction of staff. The existence of staff job satisfaction is a factor that can improve the performance of the organization to achieve a 
predetermined outcome (Tazekand et al, 2014). Job satisfaction based on the explanation of Paul Spector (1997) is how individuals perceive their work and different aspects of their work. Staff performance is highly dependent and influenced by several factors, one of which is job satisfaction (Ayodele\&Olorunsola, 2012). Since job satisfaction can be said to be an anchor for staff performance, it is important to ensure their job satisfaction in order to maximize their performance to achieve organizational goals (Butler and Rose, 2011).

Job satisfaction is a common form of a person's feelings towards his work (global Satisfaction) and aspects that are in his work (facet Satisfaction) (Raditya, 2012). Spector (1997) argues that a global approach can be used when looking at an overall attitude, for example if the organization wants to see the impact and likes of the individual on the job. Facet approach is conducted to find out which part of the work can cause satisfaction or dissatisfaction. This approach can provide complete information on individual job satisfaction. Paul Spector (1997) argues the the aspects of job satisfaction are salary, promotion, supervision, additional benefits, contingent rewards, operating conditions, co-workers, nature of work, and communication.

Job satisfaction is a crucial thing and very important to be considered by managers (supervisor). Job satisfaction affects workers in some aspects as follows.

1. Productivity

Job satisfaction is closely related to aspects of productivity. Employee satisfaction increases as it is aligned with the high productivity produced or achieved by a worker. This is supported by the group views theory, a worker will associate the work they achieve with what they receive (salary and benefits) and be recognized by the reference group. Aziri (2011) reveals that the performance shows the level of job satisfaction of a worker, and the company knows what factors influence it.

2. Loyalty

The loyalty of a worker is a factor that cannot be ruled out (Aziri, 2011). Aziri (2011) argues that there are three kinds of loyalty that must be considered, namely affective loyalty, normative loyalty, and continuity loyalty. Affective loyalty is created by a sense of what the worker feels and the worker's sense of company. Normative loyalty can be defined when the employee feels something about the company. Continuity loyalty is a form of the result of a fact that workers do not have the opportunity to look for work elsewhere.

3. Presence

Presence is a very important aspect in an organization or company. Many managers (supervisors) try to maintain the presence of workers and minimize absenteeism. Aziri (2011) argues that one of the efforts in minimizing workers' absenteeism is by increasing the level of job satisfaction of workers. This will be very important because it can affect the performance and workload of workers, if it is not managed properly, it will impact on job satisfaction in the organization.

\section{Research Methodology}

This research conducted by using survey design. Researchers do not intervene on variables, observation of this variable is done with the state as it is without any manipulation. In this research, survey research will be conducted. Fowlers (2009) argue that survey research is a research that has an effective cost, highly efficient, easy to do and accurate.

In this study, there are two variables used. These two variables consist of independent and dependent variables. Independent variable in this research is conflict management while dependent variable is job satisfaction which is one of reaction factor in work. This independent variable contains the conflict management style by Rahim (2001). Conflict management styles contain five styles: integrating (IN), obligation (OB), avoiding (AV), dominance (DO), and compromise (CO). To collect the data, questionnaire technique will be used in this research. In this study, two questionnaires will be used that aim to measure two variables of conflict management and job satisfaction. The first questionnaire uses the instrument contained in ROCI-II and this instrument will be used to measure conflict management styles. In the second questionnaire is the instrument that use Job Satisfaction Survey Spector to obtain data on job satisfaction of workers. 
This research will be conducted in public service sector institution in several government agencies in Indonesia and use quantitative approach. Populations that were subjected to the study were workers in public sector services in several districts in Indonesia. There are 19 government agencies, state-owned enterprises that include PDAM, PLN, Post Office and Regional Owned Enterprises involved in the survey. This study employs the technique of taking Quota nonprobability Sampling. Conflict management questionnaires uses ROCI-II instruments with 35 questions compiled with a score range of 35 to 175 (Rahim, 1983). The measurement uses a 5-point Likert scale and the score ranged from number 1 to strongly disagree and 5 to strongly agree. On the questionnaire of job satisfaction, Job Satisfaction Survey Paul Spector (1997) employed in the survey. In the JSS, there are 36 questions, but this study only use 28 questions and arranged with a score range of 28 to 168 . The measurement use a 6-point Likert and a score of 1 to strongly disagree and 6 to strongly agree.

Populations that are subjected to the research are employees working in the government offices. There are 141 respondents spread in several regency offices. This research uses questionnaires with ROCI-II instrument for conflict management and JSS Spector for job satisfaction. The conflict management questionnaire has reliability score of Cronbach's alpha for 0.88 and 0.74 for job satisfaction.

\section{Results And Analysis}

The result of data tabulation of descriptive analysis is used to find out what style employed by public sector employee from scores of questionnaire which will be shown in the following result:

Table. 1: Analysis of Statistical Description of ROCI-II Method

\begin{tabular}{cccl}
\hline & Mean & Std. Deviation & Total \\
\hline Integrating & 28,62 & 2.288 & 141 \\
Avoiding & 21,73 & 4.135 & 141 \\
Dominating & 19,45 & 4.532 & 141 \\
Obliging & 26.06 & 3.455 & 141 \\
Compromising & 27.41 & 2.754 & 141 \\
Job Satisfaction & 116.16 & 9.828 & 141 \\
\hline
\end{tabular}

Based on the results of descriptive analysis test with the total number of respondents is 141 individuals, the style of collaboration (integrating style) is a conflict management style that has the highest mean score of 28.62 with a standard deviation of 2.28. This result shows that collaborative conflict management style (integrating style) is a style applied by public sector workers of government agencies. Workers in Indonesia government agencies use the style of collaboration as a technical effort in solving and managing a conflict. This can be realized by exchanging information between superiors with subordinates or vice versa in order to get the best solution in solving every problem.

Compromising style in conflict management has a mean score of 27.41 and 2.75 for standard deviation. A compromise style is a form of solving a problem by considering the best deal by minimizing the difference both in superiors with subordinates and deliberate to reach consensus. In the sector of public services in Indonesia, some workers also apply this style in the organization. Compromising is also applied by workers in Croatia in its conflict management (Vokic \& Sontor, 2009).

The dominating style is the conflict management style with the lowest mean score of 19.45 with the standard deviation of 4.13. In this case, it can be interpreted that public sector workers refused or disagreed in using the style of domination in managing a conflict. Collaboration style is an effective style used in conflict management. Collaboration style is more dominant by involving 
all elements in the organization to find solutions to problems encountered. Collaboration style is technically done by sharing all information either by supervisor with staff or vice versa (Copley, 2008). The style of collaboration (integrating style) is an effective style when applied to manage a conflict and can meet the needs of both parties. Collaboration style applied by the public sector government of several public services in Indonesia.

Collaboration style also has weakness. This weakness is expressed by Vokic \& Sontor (2009) that in the style of collaboration (integrating), it takes a lot of time in its application in managing conflict. This time-consuming process is used to explore the differences between the two parties in conflict. Collaboration style performs the exploration process and thus, this style is quite time consuming in its implementation. But it is useful to align thinking and reach the best solution. This weakness can be overcome by relying on the ability of supervisors or leaders of the organization. Supervisors have a very vital role in the conflict management process. The effectiveness and efficiency of the conflict management process is strongly influenced and determined by the ability of a supervisor (Graham, 2009).

This factor analysis is performed to analyze the correlation between a large number of variables by defining a set of similarities of variables or dimensions called factors (Ghozali, 2006). This factor analysis was conducted to find out the conflict management style based on the theory of Rahim (1983) used by public sector employee of Indonesia's government agencies. The factor analysis will begin with KMO and Bartlett's tests. This test is used to determine whether or not the data were tested by factor analysis.

Table. 2: Output of Factor Analysis

KMO and Bartlett's Test

Measurement ofKaiser-Meyer-Olkin Sample $\quad 0,723$

Bartlett's Test of Approx Chi-Square $\quad 251,938$

$\begin{array}{lll}\text { Sphericity } & \text { Df } & 10\end{array}$

Sig. $\quad 0,000$

The output of KMO and Bartlett's test numbers processed using SPSS 20 obtained a value of $0.723(>0.5)$ and a significant $0.000(<0.5)$. These results explain that variables can be further analyzed.

Table. 3: Output of test factor analysis of Communalities

\begin{tabular}{lll}
\hline & Initial & Extraction \\
\hline$\left(\mathrm{X}_{1}\right)$ integrating & 1,000 & 0,782 \\
$\left(\mathrm{X}_{2}\right)$ avoiding & 1,000 & 0,773 \\
$\left(\mathrm{X}_{3}\right)$ dominating & 1,000 & 0,786 \\
$\left(\mathrm{X}_{4}\right)$ obliging & 1,000 & 0,797 \\
$\left(\mathrm{X}_{5}\right)$ compromising & 1,000 & 0,757
\end{tabular}

Rahim (1983) states that the style of conflict management is divided into five styles namely, the style of collaboration, avoidance, domination, accommodation, and compromise. The result of this communalities test shows that in five variables, it can be explained as a factor since each variable has score $>50 \%$ 
Table. 4: Output of Total Variance Factor Analysis

\begin{tabular}{cccc}
\hline \multirow{2}{*}{ Component } & \multicolumn{3}{c}{ Initial of Eigen Score } \\
\cline { 2 - 4 } & Total & Variance & Cumulative $\%$ \\
\hline 1 & 2,666 & 53,314 & 53,314 \\
2 & 1,223 & 24,453 & 77,767 \\
3 & 0,424 & 8,483 & 86,250 \\
4 & 0,393 & 7,852 & 94,102 \\
5 & 0,295 & 5,898 & 100,000 \\
\hline
\end{tabular}

Factor 1 has the total eigenscore of 2.666. Factor 1 has a variance value of 53.314 obtained from $\left(\frac{2,666}{5} \times 100 \%=53.314 \%\right)$. Variance can be concluded that factor 1 can explain the existence of 5 conflict management style to $53.314 \%$. Factor 2 has a score of 1.223 , and has a score of $\%$ variance of $24.453 \%\left(\frac{1,223}{5} \times 100 \%=24.453 \%\right)$. Variant score of $24.453 \%$ can be interpreted that factor 2 explains the existence of 5 conflict management style in the factor of $24.453 \%$. The total factor accumulated score is composed of both factors, namely $77.767 \%$ of the five conflict management styles existed in factors 1 and 2.

Table. 5: Output Analysis of Matrix Component Rotation Factor

Component

\begin{tabular}{lcc}
\cline { 2 - 3 } & 1 & 2 \\
Integrating $\left(\mathrm{X}_{1}\right)$ & 0,880 & $-0,087$ \\
Obliging $\left(\mathrm{X}_{4}\right)$ & 0,842 & 0,297 \\
Compromising $\left(\mathrm{X}_{5}\right)$ & 0,801 & 0,330 \\
Dominating $\left(\mathrm{X}_{3}\right)$ & 0,085 & 0,883 \\
Avoiding $\left(\mathrm{X}_{2}\right)$ & 0,201 & 0,856 \\
\hline
\end{tabular}

The result above mentioned that component matric rotation test is clearly existed on two available factors. The largest correlation on factor 1 is the collaboration style (integrating) with the score of 0.880 , then the style of accommodation (obliging) with a score of 0.842 , and the last is compromising style with a score of 0.801 . On the second factor, the biggest correlation is dominating style with score of 0,883 , and followed by avoiding with score of 0,856 . Based on the results of factor analysis, factor 1 (collaboration style (integrating), accommodation (obliging), and compromising) is a conflict management style that is more used by public workers to manage and handle a conflict.

In general, conflict management style has its own influence for the individuals in the organization. In the analysis of conflict management style factors that have been done, two factors formed from the previous five factors, consisting of factors 1 and 2 . Factor 1 is a conflict management style that is more applied and used by workers in the public sector regarding the management conflict.

The tendency to not use Factor 2 (Style of domination and avoiding) is to minimize new problems that will arise when one problem is solved. Public sector workers likely try to solve the problem without arising any new problems. The public sector works as a social function to serve the needs of the public. In the activity, organizations integrated in one unity, and the style of domination and avoidance is not appropriately applied. For example, Rahim (2001) argues that avoidance style is not appropriate when the issue is very important to the organization and requires an immediate decision. In the style of domination is not appropriately applied since the character is more likely to care for themselves (Rahim, 2001). 
Table. 6: Normality Test

\begin{tabular}{cccc}
\hline & (y)Job Satisfaction & Factor 1 & Factor 2 \\
\hline $\mathrm{N}$ & 141 & 141 & 141 \\
Sig. & 0,056 & 0,445 & 0,886
\end{tabular}

There are 141 sample in this research. From the information of table 6 above, it can be concluded that the data has distributed normally on both Job Satisfaction (Y), Factor 1 $\left(\mathrm{X}_{1}\right)$ and Factor $2\left(\mathrm{X}_{2}\right)$.

Table. 7: Multicolonierity Test

\begin{tabular}{cccc}
\hline \multirow{2}{*}{ Model } & \multicolumn{2}{c}{ Colonierity statistics } & \multirow{2}{*}{ Sig } \\
\cline { 2 - 3 } & Tolerance & VIF & \\
\hline Factor 1 & 1,00 & 1,00 & 0,000 \\
Factor 2 & 1,00 & 1,00 & 0,232 \\
\hline
\end{tabular}

A good regression model is a model with no correlation among independent variables. Determining the presence or absence of multicollonierity in this study is done by looking at the score of VIF (variance inflation factor) and tolerance. Table 7 shows that on the research regression model, there is no multicolonierity. Factor 1 and 2 have a tolerance score of $1(>1)$, and VIF $1(<10)$. There is multicolonierity in a regression model if the score is tolernce $(<!)$ and $\operatorname{VIF}(>10)$.

Figure. 1: Scatterplot graph of heteroskesdasticity test

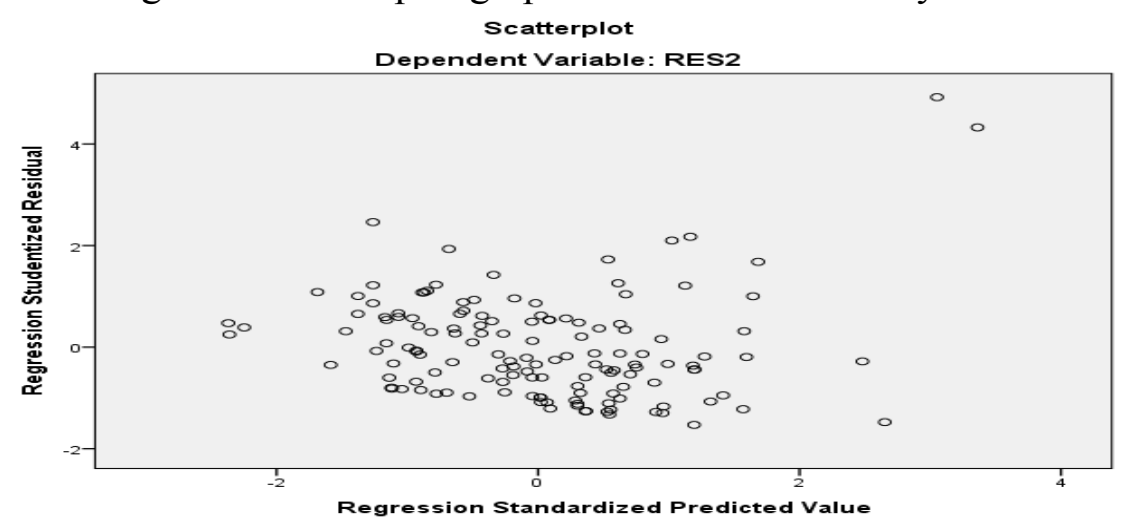

Knowing heteroskesdacity can be done by looking at the presence or absence of a particular pattern on the scatterplot chart. This decision is made with the following rule:

a. If there is a certain pattern, it indicates that there is a problem of heteroskesdasticity.

b. If there is no clear or diffuse pattern, and dots

c. Spread above and below 0 on the y-axis then no heteroskesdasticity 
The graph above shows the spots spread above and below the number 0 on the $\mathrm{Y}$ axis. The points do not form a certain pattern, thus in this study there is no problem heteroskesdasticity.

This study consisted of 141 respondents who filled the questionnaire. The respondents are workers in several government agencies in Indonesia. Significance on the relationship of variable $\mathrm{X}$ (conflict management style) to $\mathrm{Y}$ (job satisfaction) will be tested by using multiple linear regression analysis.

Table. 8: Regression Analysis of Multiple Linear

\begin{tabular}{cccc}
\hline & $\begin{array}{c}\text { Coefisient } \\
\text { Beta }\end{array}$ & $\mathrm{t}$ & Sig. \\
\hline Constantity & 116,163 & 152,325 & \\
Factor 1 & 3,861 & 5,045 & 0,000 \\
Factor 2 & 0,918 & 1,199 & 0,232 \\
R Square & 0,163 & & \\
F & 13,446 & & 0,000 \\
\hline
\end{tabular}

Table 8 shows that factor 1 has an influence on job satisfaction, while factor 2 does not give a significant effect on job satisfaction. The regression coefficient can be known by regression equation $\mathrm{Y}=116,163+3,861$ Factor $1+0,918$ Factor 2 . R2 score is obtained $0.163(16,3 \%)$.

Conflict management style had an effect of $16.3 \%$ on job satisfaction. The score of $\mathrm{R} 2$ in this study is very low, but it does not mean that this research is not good. Insukindro (1998) argues that the coefficient of R2 is just one and not the only criterion that explains a good research model. This research get result of $\mathrm{F}$ test count for 14.446 with significance score of $0.000(95 \%, \alpha=0,05)$. Result of this $\mathrm{F}$ test showed that the style of conflict management gives a significant influence on job satisfaction. The conclusion is taken from 13.446> 3.06 (Fobtain $>$ Ftabel).

Table 8 shows that factor 1 has a significant influence on job satisfaction while factor 2 does not give effect. Factor 1,including the style of conflict management of collaboration (integrating style), compromise (compromising style), and accommodation (obliging style), has a significant effect on job satisfaction of 3.861 with significance score of $0,000(<0,05)$. Factor 2,including dominating style and avoiding style, has no significant effect on job satisfaction with score of $0.232(>0,05)$. Factor 1 has a t score of 5.045 and factor 2 of 1.977 . If $t$ obtain $>t$ table, it can be concluded that variable $X$ gives influence on variable $Y$. In this research, Factor 1 affects job satisfaction since 5.045> 1.977 with 0.000 significance and gives the effect of 0.393 to job satisfaction. Factor 2 has no effect on job satisfaction, because $1.199<1.977$, with significance of 0.232 .

Job satisfaction is a reaction factor that arises through the worker's sense of work and the work environment (Mehrad, 2015) and also the existence of the influence of the ability of a supervisor or manager in an organization to maintain job satisfaction of workers. Conflict management styles can be very important in an organization in both the public and private sectors.

From the results of the analysis above, it was found that the style of collaboration (integrating), compromise (compromising), and accommodation (obliging) incorporated in factor 1 affect the job satisfaction. In the study of Ahmed (2015) it was found that there was 
a positive correlation between the conflict management style on job satisfaction in the public sector. The study found that avoiding style is positively correlated with job satisfaction.

Indonesia is known to collaborate in working to achieve the goal. The style of collaboration, compromise and accommodation is very appropriate to be carried out. The three styles of conflict management in its technical implementation is done by solving the problem together. In the policy-making process, there are differences of opinion so that it needs collaboration between sections within the organization. This style of collaboration is most appropriate when it comes to managing differences, considering the character of one who cannot decide a unilateral decision and needs to integrate ideas from all concerned (Rahim, 2001). Good conflict management will increase job satisfaction and minimize the negative impact that conflict will cause. This is in line with Williams (2001) who believes that effective conflict management will increase morale, productivity, employee and customer satisfaction and if it is not handled properly, it will have an impact on decreasing job satisfaction and on declining performance.

Combining ideas from all parties to find solutions is a good way to maintain relationships among workers. Weider-Hartfield and Hartfield (1995) argue that the implementation of collaborative conflict management styles is less significant to interpersonal, intragroup and intergroup conflicts than non-collaborative styles. To minimize the emergence of distance relationships that lead to conflict both on superiors and subordinates, then the style of accommodation is good to use. Rahim (2001) states that accommodation styles are best used to maintain the relationships of workers. Compromising styles can be applied to help obtaining temporary solutions when collaborative styles are not successful (Rahim, 2001). This temporary solution is used to minimize the conflicts of intragroup and intergroup.

Factor 2 has no effect on job satisfaction. Public sector workers tend to refuseusing the dominating and avoiding style in managing the existing conflict. The results can be seen in table 4.7. Vokic and Sontor (2009) reveal that in general, the workers need equal recognition in the relationships between workers and reject to have a relationship that is not harmonious in the work environment. This is also applied by public sector workers in government agencies.To workin the organization, they tend to use collaborative conflict management style, compromise and accommodation to manage conflict in order to maintain job satisfaction within the organization and solid worker relationship so that organizational goals can be achieved.

\section{Research Limitation and Future Direction}

This study has several weaknesses and limitations. Research that was conducted is in general, without separating the level of position of management. Different position of level of management in government agencies could give variation in their perception of conflict management. In this study we do not develop the measurement of conflict handling. The consequence of this, we do not have information of how employee coping with conflict in their organization.

Conflict management is a topic that has been widely discussed and conducted research. Conflict management is a vital and crucial topic, from the experience of researchers, there are still many people interpret conflict as a taboo subject during research. This may be due to lack of information on conflict management. The results of this study are expected to contribute to academics especially conflict management themes. This study also gives an overview of what conflict management style used by public sector workers of Boyolali District government and its effect on job satisfaction. The results of this study are expected to be basic information for academics to conduct conflict management research on job satisfaction with different variables such as performance, leadership style and so on. 
Conflict management is a vital and crucial topic. Researchers hope that in the future, there will be further research on conflict management styles. Researchers expect future research to be more specific. Specifically by dividing the level of position and conducted on two different organizations though still in one sector, for example research conducted on the agency, Regional Owned Enterprises, and State Owned Enterprises). It will provide deeper and more detailed information on the conflict management style.

\section{Conclusion}

There are 5 (five) factors found in the conflict management style. However, ther is only two factors after conducting the analysis of factors. These two factors consist of factors 1 and 2 . Factor 1 includes style of collaboration (integrating style), accommodation (obliging style), and compromise (compromising style). In factor 2, there are dominating style, and avoidance (avoiding style). From the five conflict management styles, the style of collaboration (integrating style) is the style used by the public sector workers of government agencies to handle and manage a conflict. Five factors can explain as a variable, but only two factors are formed. The highest score is on the style of collaboration (integrating style) with a core of 0.880 . The main factors consist of style of collaboration (integrating style), accommodation (obliging style), and compromise (compromising style).

The results of this study show that the style of conflict management gives a significant effect on job satisfaction. Researcher recommend supervisors to use the results of this study as a basic information and suggestion that can be used to create policies on issues of human resource development, especially conflict management in the work environment of government public services.

Conflict can be called as the initial process to move forward. It means that conflict is not a bad thing if the management is properly handled. Conflict can be an individual trigger within the organization to grow better, in this case is performance.

From the research, it was seen that the public sector of government organization tends to use the style of collaboration in the management and handling conflict, and this is a good step for the government agencies. Style collaboration is a style that tries to find a win-win solution and able to create organizational innovation. Style of collaboration in character shows high concern for both self and also for others. It can be concluded that the public sector of government agencies in Indonesia has a good relationship between workers in one organization, either between superiors to subordinates and vice versa.

Hopefully this result becomes valuable information for the government agencies in Indonesia. Since this study states that conflict management influencesjob satisfaction. The second suggestion is about the conflict management style used. Collaborative conflict management style, accommodation and compromise are conflict management styles that gives a significant influence on job satisfaction. The researcher hopes that the public sector always uses the style of collaborative conflict management because it can contribute to the organization as well as to maintain job satisfaction of public sector, and able to increase the commitment and performance of the employees of government services in Indonesia.

\section{References}

Aziri, B. (2011). Job Satisfaction: A Literature Review. Management Research and Practice, 3, 77-86.

Ahmed, K. G,. (2015). The Relationships Between Conflict Management Styles, Job Satisfaction And Organizational Commitment Among Workers in Public And Private Sectors. Universal Journal of Psychology 3, 41-50. 
Ayodele, J. B., \& Olorunsola, E.O. (2012). The Relationship Between Job Satisfaction And Performance Of Administrative Staff In South West Nigeria Univesities. Journal of Psychology, vol 30(3), 313-316.

Beheshtifar,. M. \& Zare, E. (2013). Interpersonal Conflict: A Substantial Factor to Organizational. International Journal of Academic Research in Business and Social Sciences. Islamic Azad University, Iran.

Christensen, T., Laegreid, P., Roness, G., P., \& Rovik, A., K. (2007). Organization Theory And The Public Sector: Instrument, Culture, And Myth. Routledge Taylor \& Francis Group, London.

Copley, R., D. (2008). Conflict Management style: A Predictor of Likability and Perceived Effectiveness Among Subordinates. Indiana University.

Fowler, F., L. (2009). Survey Research Methods. Sage Publications, Inc.

Ghozali, I. (2006). Aplikasi Analisis Multivariate Dengan Program SPSS. Badan Penerbit Universitas Diponergoro, Semarang.

Graham, S. (2009). The Effects of Different Conflict Management Styles on Job Satisfaction in Rural Healthcare Settings. Economics \& Business Journal: Inquiries \& Perspectives. Vol 2:1.

Lewin, K. (1948). Resolving Social Conflicts: Selected Papers On Group Dynamics. Ed. G. W. Lewin. New York: Harper \& Low.

Maharjan, S. (2012). Association Between Work Motivation And Job Satisfaction Of College TeacherS. Journal of Administrative and Management Review, 24(2), 4555

Mahmudi. (2007). Manajemen Kinerja Sektor Publik. Yogyakarta: Sekolah Tinggi Ilmu Manajemen YKPN.

Mehrad, A. (2015). Conflict Management Styles And Staff Job Satisfaction At Organization. Journal of Educatiobal, Health and Community Psychology. Vol 4, No 2.

Miller, P,. E. (2007). The relationship between job satisfaction and intention to leave: A study of hospice nurses in a for-profit corporation. 3246088 Ph.D., Capella University, Ann Arbor.

Nastase, M.(2007). Types of Organizational Conflicts. Revista de Management Comparat Internacional. Vol 8. Romania.

Quijada, M., A. (2016). Heavy Metal Conflict Management. Management Teaching Review, Vol 1, 155-163.

Prasad, B., \& Junni, P. (2017). Understanding Top Management Team

Conflict,Enviromental Uncertainty And Firm Innovativeness: Empirical Evidence

From India. International Journal of Conflict Management, vol 28, 1-38.

Raditya, D. (2012). Analisis Pengaruh Manajemen Konflik dan Kepuasan Kerja pada Direktorat Jenderal Perkebunan Kementerian Pertanian RI Fakultas Ekonomi Program Studi Magister Manajemen. Universitas Indonesia. Jakarta.

Rahim, M., A. (1983). A Measure of styles of handling interpersonal conflict. Academy of Management Journal, 26, 368-376.

Rahim, M., A. (2001). Managing Conflict in Organizations (3rd ed). Westport, London: Quorum book.

Spector, P. (1997). Job Satisfaction: Application, Assesment, Cause And Consequences. Sage Publications.

Tazekand, E., F., Nafar, N., \& Keramati, R. (2013). The Relationship Between Marital Satisfaction And Job Satisfaction Among Employees Of Social Welfare Organization At Tehran Branches. Journal of Life Science, 10(6s), 804-812. 
Thompson, L. (1998). The Mind And Heart Of The Negotiator. Upper Saddle River, NJ: Prentice-Hall.

Vokic, N., P., \& Sontor, S. (2009). Conflict Management Styles in Croatian Enterprises The Relationship between Individual Characteristics and Conflict Handling Styles. University Of Zagreb, Faculty Economics and Business. Zagreb, Croatia. Vol 09-05.

Wahyudi, A. (2015). Konflik, Konsep Teori dan Permasalahan. Universitas Tulungagung: Tulungagung.

Weider-Hartfoeld, D., \& Hartfoeld, J. (1995). Relationship Among Conflict Management Styles, Levels Of Conflict, And Reactions To Work. Journal of Social Psychology. Vol 135(6), 687-698. PorQuest.

Williams, I., A. (2011). Conflict Management Styles And Job Satisfaction By Organizational Level And Status In A Private University. UMI number 3492567. ProQuest LLC.

Wirawan. (2009). Conflict management. Jakarta: Salemba Humanika. 